\title{
DOES PARENTAL INVOLVEMENT REALLY MAKE A DIFFERENCE? A STUDY WITH PARENTS OF PRIMARY SCHOOL STUDENTS IN URBAN CONTEXT
}

\author{
Raquel Barroso ${ }^{1}, \&$ Diana Dias ${ }^{1,2}$ \\ ${ }^{l}$ CIPES - Center for Research in Higher Education Policies (Portugal) \\ ${ }^{2}$ Universidade Europeia (Portugal)
}

\begin{abstract}
School and family are the closest and most powerful systems in child development. Previously, family is assumed as the main promoter of the child's education, who, inserted in this environment, became aware of social norms and culturally suitable behaviours. However, early family share their responsibility with several other educational entities, especially with the school. In fact, parental engagement in school and its role in the emotional and academic adjustment of children and adolescents has been the subject of multiple studies. Thus, parental engagement is seen as an important resource for the promotion of student learning and development, because it could be changeable, and it is one of the variables more susceptible to intervention, compared to other family characteristics, such as socioeconomic level or parental educational styles. So, the present study aims to explore not only the parental engagement of students in the 3rd year of primary school, but also analyse the relationship between parental engagement and their sociodemographic features. In this study, a sample of 556 Portuguese parents was used, from the Lisbon and Porto districts, whose children are at the 3rd year of the primary school. The data was collected through a sociodemographic questionnaire built within the scope of a largest research and the Parental Engagement Questionnaire (PEQ). PEQ is a self-report questionnaire that assesses parental engagement in the school context through four factors: parental engagement in school and volunteer activities, family engagement in home-based learning activities, school-family communication, and parental engagement in school activities, such as participation in parent-teacher meetings. The results seem to point out that participating parents perceive their engagement in the school context as relevant and high. The results also show the influence of the various forms of parental engagement, since parents who present higher values in one of the parental engagement subscales tend to present the same results in the others as well. The influence of several sociodemographic variables on parental engagement was also verified. The place of data collection (Porto or Lisbon) was also related to parental engagement in several analysed factors. The results attained will be discussed in the light of the most recent literature on educational psychology, and its practical and research implications are also discussed.
\end{abstract}

Keywords: School parental engagement, primary school, education, school success.

\section{Introduction}

Family plays a fundamental role in social relationships and in the increasingly complex and challenging learning experiences that occur in children's lives, being consensual that children need a family that provides them with emotional, cognitive and material support, that enhances their development and allows them to grow healthily (Berger, 2000). So, the relationships established between parents and children are essential, since parents are the first agents of socialization of children, at the behavioural, emotional and cognitive levels (Piccinini, Frizzo, Alvarenga, Lopes \& Tudge, 2007), being determinant for the success of children at various levels. The family, especially the parents, are engaged, in the various stages of their children's development, both in informal moments and activities, as in their process of schooling (Eccles \& Harold, 1996). Parental engagement in school has warranted the attention of research as one of the variables of the family context with implications in children's academic success (Epstein, 1987; Hill \& Tyson, 2009; Wilder, 2013). In truth, it encompasses various behaviours and attitudes of parents to provide educational resources to support the development and learning of their children (Grolnick \& Slowiaczek, 1994). Currently, this construct is considered as important as other elements of the individual's educational process, since it can relate to several aspects related to schooling, both related to schools as physical spaces and also as spaces of fundamental interactions for the development of children and professionals (Bhering, 2003). 
Parental engagement in education points to the understanding of the complex interactions between parenting motivation, existing family interaction, students' learning, the methods adopted by teachers at school, the school climate, and the intervention strategies. It is important to promote links between the family, the school and the community, since that, in addition to improving the entire school context, they can also help families communicate with each other and with their surrounding contexts. However, the main reason for promoting a partnership between family, school and community is to help children and young people achieve personal and school success, where parents and teachers should consider themselves partners in education and success promoters (Epstein, 2001).

Thus, the present study aims to characterize the parental involvement of students in the 3rd year of primary school, also analysing the relationship between established parental engagement and their personal and social traits.

\section{Methodology}

\subsection{Participants}

556 parents or guardians responsible for the child's education, whose children attend the 3rd year of primary school, participated in this study, from which 471 parents were mothers $(84.7 \%), 70$ were parents $(12.6 \%)$ and 15 were another reference figure for the child $(2.7 \%)$. The parents of the 556 students were aged between 24 and $65(M=40.90, S D=4.65)$ and mothers between 20 and 56 years $(M=38.39, S D=6.00)$, with a mean of 1.99 children $(S D=0.89, \operatorname{Min}=1, \operatorname{Max}=6)$. The majority were families from the Porto district $(64.7 \%)$, but $32.9 \%$ belonged to the district of Lisbon. On average, the children lived $3.96 \mathrm{~km}$ away from the school they attended $(S D=19.41, \operatorname{Min}=0, \operatorname{Max}=100)$.

\subsection{Instruments}

The sociodemographic data was obtained by filling out an individual identification form built in the scope of the present research. Parental engagement in the school context was evaluated through the parental version of the Parental Engagement Questionnaire [18]. This is a self-report questionnaire composed of 24 items answered on a 4-point Likert scale (from Totally Disagree to Totally Agree). This is an instrument made up of 4 factors or subscales.

The first factor consists of items belonging to the family engagement dimension in activities at school, being it designated by parental engagement in school activities and volunteering $(\alpha=.83)$. The items that make up this scale refer mainly to the availability and desire of the parents to participate actively and to organize different activities in the school space, assuming a more proactive rather than reactive engagement. The second factor consists of all the items of the family engagement dimension in home-based learning activities, entitled parental engagement in home-based learning activities $(\alpha=.80)$. The third factor refers to school-family communication $(\alpha=.75)$, especially to communication that derives from the parents' initiative. The fourth factor concerns parental engagement in school activities and participation in parent-teacher meetings $(\alpha=.75)$ and emphasizes the more traditional ways of parental engagement in school.

This questionnaire enables the delivery of 5 score results: an overall score, which is obtained from the sum of the 24 items of the questionnaire (ranging from 24 to 96 points) and concerns the overall parental engagement and 4 scores related to each of the subscales.

\subsection{Procedures}

This research obtained a positive opinion from the Ethics Committee of the Universities to which the authors affiliate and from the Directorate General for Education to carry out research in a school context.

A representative sample of 3rd year students from the primary school was selected to take part in the study and the National Confederation of Parents' Associations, the National Association of Directors of School Districts and Public Schools and the National Association of Teachers were established as research partners. After the first contact made by one of the research partners to the selected school districts, study aims were explained. Whenever a positive response was obtained, a second contact was made to all school districts by the researchers for a more detailed explanation of the aims of the study, sending an informed consent and scheduling of the data collections.

All parents or guardians responsible for the children's education were asked to fill in an informed consent. All school districts also filled in an informed consent.

Data was analysed using IBM SPSS, version 25.0 for Windows (IBM Corp. Released, 2015). The normality of the distribution of variables was verified, as well as the homogeneity of variances. When the assumptions for using the parametric tests were not assured, the statistical treatment of the data was performed using the corresponding non-parametric tests. However, once the results were concordant, it was decided to present the results of the parametric tests, following a recommendation by Fife-Schaw (2006). 


\section{Results and discussion}

\subsection{School parental engagement characterization}

Table 1 presents the descriptive measures of school parental engagement, as well as the correlations between these variables.

Table 1. Intercorrelations and descriptive measures of school parental engagement of participating parents.

\begin{tabular}{|c|c|c|c|c|c|}
\hline & 1 & 2 & 3 & 4 & 5 \\
\hline $\begin{array}{l}\text { 1. Parental engagement in school activities } \\
\text { and volunteering }\end{array}$ & 1 & & & & \\
\hline $\begin{array}{l}\text { 2. Parental engagement in home-based } \\
\text { learning activities }\end{array}$ & $.42 * *$ & 1 & & & \\
\hline 3. School-family communication & $.44 * *$ & $.73 * *$ & 1 & & \\
\hline $\begin{array}{l}\text { 4. Parental engagement in school activities } \\
\text { and participation in parent-teacher } \\
\text { meetings }\end{array}$ & $.59 * *$ & $.46^{*}$ & $.52 * *$ & 1 & \\
\hline 5. Global parental engagement & $.79 * *$ & $.78 * *$ & $.80 * *$ & $.74 * *$ & 1 \\
\hline$M(S D)$ & $\begin{array}{c}2.33 \\
(0.73)\end{array}$ & $\begin{array}{c}3.54 \\
(0.39)\end{array}$ & $\begin{array}{c}3.45 \\
(0.46)\end{array}$ & $\begin{array}{c}3.22 \\
(0.59)\end{array}$ & $\begin{array}{c}75.44 \\
(10.76)\end{array}$ \\
\hline Scale range & $\begin{array}{c}1.00- \\
4.00\end{array}$ & $\begin{array}{c}2.28- \\
4.00\end{array}$ & $\begin{array}{c}1.83- \\
4.00\end{array}$ & $\begin{array}{c}1.00- \\
4.00\end{array}$ & $\begin{array}{c}24.00- \\
96.00\end{array}$ \\
\hline
\end{tabular}

Note: $* p<.05 ; * * p<.01$

The means obtained in the various factors of the questionnaire ranged from 2.33 (parental engagement in school activities and volunteering) and 3.54 (parental engagement in home-based learning activities), which seems to show that parents consider their role in the school more related to their contribution at home, to promote and stimulate the children's learning than to their contribution in the tasks that can be carried out at school. The results obtained in the global parental engagement result were quite high $(M=75.44)$, which seems to highlight the importance that parents seem to attribute to their children's schooling and to themselves as agents that can also play a preponderant role in the academic life of their students.

It was also found that the various factors correlated significantly with each other in a moderate or strong way. The existence of these correlations seems to show that parents who tend to be more engaged in the academic life of their children seem to do so in all their dimensions, investing significantly in the various tasks that the parental engagement with the school implies.

\subsection{Relations between school parental engagement and their personal and social traits}

Aiming to analyse the relationships between school parental engagement and the sociodemographic variables, mean differences and correlations between the factors evaluated and the different sociodemographic variables were performed.

It was verified, as shown in table 2, that there were significant differences related to the gender of the parent responsible for the child's education.

Table 2. Differences in school parental engagement associated to the gender of the parent responsible for the child's education.

\begin{tabular}{lcccc}
\hline & Mother & Father & $t$ & $d f$ \\
\cline { 2 - 5 } & $M(S D)$ & $M(S D)$ & & \\
\hline $\begin{array}{l}\text { 1. Parental engagement in school } \\
\text { activities and volunteering }\end{array}$ & $2.36(0.72)$ & $2.11(0.72)$ & $2.66^{* *}$ & 539 \\
$\begin{array}{l}\text { 2. Parental engagement in home- } \\
\text { based learning activities }\end{array}$ & $3.55(0.40)$ & $3.50(0.41)$ & 0.87 & 539 \\
$\begin{array}{l}\text { 3. School-family communication } \\
\text { 4. Parental engagement in school }\end{array}$ & $3.46(0.45)$ & $3.41(0.51)$ & 0.76 & 539 \\
activities and participation in parent- & $3.24(0.58)$ & $3.11(0.66)$ & 1.19 & 539 \\
teacher meetings & & & & \\
5. Global parental engagement & $75.74(10.80)$ & $73.80(10.38)$ & 1.41 & 539 \\
\hline Note:** $p<.01$ & & & &
\end{tabular}

Note: $* * p<.01$ 
When the mothers are the person responsible for the child's education, there seems to be a greater parental engagement in school activities and volunteering, compared to those in which the parent responsible were the fathers, and these differences are statistically significant. Mothers seem to be more available for the less traditional dimensions of parental engagement, such as participation in school trips, end of the year celebrations, when compared to fathers. These differences can be explained by the different social roles that men and women play in society, with women being generally more available and open to participation in education and child-care activities when compared to men, who focus more on their professional life. This may also explain the greater predominance of mothers as the person responsible for the child's education.

The correlation between the age of the mother and the father, the number of children and the distance from the school that children attend with their parental engagement were also analysed.

There was a significant correlation between the age of the father and the parental engagement factor in school activities and participation in parent-teacher meetings $(r=0.10, p<.005)$. The same correlation was observed between the age of the mother and the same factor, parental engagement in school activities and participation in parent-teacher meetings $(r=0.15, p<.001)$, which seems to demonstrate that the older the parents, the more they participate in school activities.

These results can be due to several reasons: on the one hand, older parents can be more available and, for this reason, find it easier to attend the activities; on the other hand, they can value more these face to face and more traditional activities of the parental engagement. These results and these explanations are further reinforced when there is a correlation between the age of the mothers and the overall engagement with the school $(r=.13, p<.01)$, that is, older mothers tend to become more engaged in the school.

The existence of some relationships between the number of children and parental engagement was also evidenced. The more children the participants had the less engagement there is in learning activities at home $(r=-.10, p<.05)$ and the lower school-family communication $(r=-.12, p<.05)$ was. These results may be due to the need for these participants to share their attention with more children, who may also attend the educational system, and also require the attention of their parents to these issues.

No relationship was found between distance to school and parental engagement.

Finally, we analysed the existence of significant differences between the factors evaluated and the place where the data collection took place (Porto or Lisbon). As can be seen in Table 3, there were significant differences between the parents' parental engagement, depending on whether they lived in Porto or in Lisbon.

Table 3. Differences in school parental engagement associated to the location of data collection.

\begin{tabular}{|c|c|c|c|c|}
\hline & Porto & Lisbon & $t$ & $d f$ \\
\hline & $M(S D)$ & $M(S D)$ & & \\
\hline $\begin{array}{l}\text { 1. Parental engagement in school } \\
\text { activities and volunteering }\end{array}$ & $2.33(0.72)$ & $2.27(0.73)$ & 1.04 & 541 \\
\hline $\begin{array}{l}\text { 2. Parental engagement in home- } \\
\text { based learning activities }\end{array}$ & $3.56(0.39)$ & $3.48(0.41)$ & $2.23 *$ & 541 \\
\hline 3. School-family communication & $3.49(0.42)$ & $3.36(0.53)$ & $3.17 * *$ & 541 \\
\hline $\begin{array}{l}\text { 4. Parental engagement in school } \\
\text { activities and participation in parent- } \\
\text { teacher meetings }\end{array}$ & $3.29(0.53)$ & $3.07(0.68)$ & $4.05 * * *$ & 541 \\
\hline 5. Global parental engagement & $76.38(9.65)$ & $72.91(12.30)$ & $3.60 \mathrm{P} * * *$ & 541 \\
\hline
\end{tabular}

Note: $*<.05, * * p<.01, * * * \mathrm{p}<.001$

Parents from Porto are more engaged in learning activities at home, in school-family communication, in school activities in teacher-parent meetings and in school in a more general way, when compared to the parents of students in Lisbon.

This result is the most unexpected. All children attend public education, present similar contextual characteristics among themselves, and it is not possible to explain this result. Further research will be needed on the different variables that may interfere with parental engagement in the school context in order to explain this result. 


\section{Conclusions}

The purpose of this study was to characterize the parental engagement in the school context of parents of the 3rd year of primary school, as well as the exploration of the relationships between this parental engagement in the school context and their personal and social traits. For this purpose, a self-response questionnaire was used, which evaluates parental engagement through four factors: (a) parental engagement in school activities and volunteering, (b) parental engagement in home-based learning activities, (c) school-family communication, and (d) parental engagement in school activities and participation in parent-teacher meetings; and a summation of global parental engagement.

The results seem to show that participating parents perceive their engagement in the school context as relevant and high. The results also show the influence of the various forms of parental engagement, since parents who present higher values in one of the parental engagement subscales tend to present the same results in the others as well.

There was also a congruence between the results obtained in the present study and the results of the literature on the subject, in which the influence of sociodemographic variables is related to the presence of several relationships between the various sociodemographic variables and parental engagement. However, a surprising result was obtained, since the place of data collection (Porto or Lisbon) was related to the parental engagement in several factors analysed. Further research will be needed to better understand this result.

\section{References}

Berger, K. (2000), O desenvolvimento da pessoa da infância à Terceira idade. Nova Iorque: LTC.

Bhering, E (2003), Perceções de pais e professores sobre o envolvimento dos pais a educação infantil e ensino fundamental, Contrapontos, 3, 3, 483-510.

Eccles J., \& Harold R. (1996), Family involvement in children's and adolescents schooling in Family-school links: How do they affect educational outcomes (A. Both Orgs.), 1-31, Hillsdale, NJ: Lawrence Erlbaum Associates.

Epstein J. (1987), toward a theory of family-school connections: Teacher practices and parent involvement across the school years In Social intervention: Potential and constraints (K. Hurrelmann, F. Kaufmann, and F. Losel Orgs.), 121-136, New York: DeGruyter.

Epstein J. (2001), School, Family and Community Partnerships. United States of America: Westview Press.

Fife-Schaw, C. (2006), Levels of measurement In Research methods in psychology (G. Breakwell, S. Hammond, C. Fife-Schaw, and J. Smith Orgs.), 50-63, London, England: Sage.

Grolnick, W. \& Slowiaczek M. (1994), Parents' involvement in children's schooling: A multidimensional conceptualization and motivational model, Child Development, 65, 237-252. doi: 10.2307/1131378

Hill N. \& Tyson S. (2009), Parental involvement in the Middle School: A Meta-Analytic Assessment of the Strategies That Promote Achievement, National Institutes of Health, 45, 3, 740-763. doi: $10.1037 / \mathrm{a} 0015362$

Piccinini, C., Frizzo G., Alvarenga P., Lopes R., \& Tudge, J. (2007). Práticas educativas de pais e mães de crianças aos 18 meses de idade, Psicologia: Teoria e Pesquisa, 23, 4, 369-378. doi: 10.1590/S0102-37722007000400002 